ISSN 2658-4824 (Print), 2713-3095 (Online)

УдК 792.5

DOI: 10.33779/2658-4824.2021.1.075-089

\section{А.П. ГРУЦЫНОВА}

Московская государственная консерватория имени П.И. Чайковского

2. Москва, Россия

РАТИ - ГИТИС

ORCID: 0000-0003-4014-4722

anna_gru@mail.ru

\section{ANNA P. GRUTSYNOVA}

Moscow State P.I. Tchaikovsky

Conservatory

Moscow, Russia

Russian Institute of Theatre Arts

ORCID: 0000-0003-4014-4722

anna_gru@mail.ru

\section{Балет «Свадьба Пелея и Фетиды» (1653), сохранившийся в изображениях}

Статья посвящена балету «Свадьба Пелея и Фетиды", который был поставлен в 1653 году в парижском дворце Пти-Бурбон, чтобы (по правилам французского театра того времени) дополнить одноимённую оперу Карло Капроли. Основой для сюжета постановки послужил широко распространённый в искусстве миф о смертном Пелее и нереиде Фетиде, преобразованный в соответствии с эстетикой того времени. Танцевальные entrée следовали после каждой сцены итальянской оперы и были связаны с её содержанием, в свою очередь образовывая последовательное, логично выстроенное повествование. Изданное либретто весьма ярко и образно передаёт содержание, а иногда и внешний облик действия. Сохранилось и описание декораций и машин, применённых в балете, благодаря чему в наше время можно составить визуальное впечатление от постановки. Кроме того, важными уточняющими подробностями, способными дать представление не только о внешнем виде персонажей, но и о конкретном распределении ролей между исполнителями, являются эскизы множества костюмов, дошедших до нашего времени. Таким образом, оказывается, что в музыкальном спектакле XVII века значительную роль играло его визуальное решение, которое, сохранившись

\section{The Ballet "Les Noces de Pelée et de Thetis" (1653) Preserved in Visual Images}

The article is devoted to the ballet "Les Noces de Pelée et de Thetis" which was produced in 1693 in the Petit Bourbon Palace in Paris (according to the rules of the French theater of that time period) in order to complement the opera with the same name composed by Carlo Caproli. The basis for the plot of the production was the myth widely disseminated in art works about the mortal Peleus and the Nereid Thetis, transformed in correspondence with the aesthetics of that time. The Dance entrées followed each scene of the Italian opera and were connected with its each content, in its turn, forming a consistent, logically delineated narration. The published libretto conveys the plot, and at times the outer form of the action quite vividly and figuratively. A description of the decorations and machines used in the ballet has also been preserved, as the result of which in our time it becomes possible to create a visual impression from the production. In addition, important defining details capable of providing a perception not only of the protagonists' outward appearances, but also of a concrete distribution of roles between the performers are the sketches for numerous costumes preserved up to our time. Thereby, it turns out that in 17th century musical performance a considerable role is played by its visual solution, which, having been preserved in iconographic materials, is capable of helping create 
в иконографических материалах, способно через несколько столетий помочь создать впечатление от общего замысла постановки.

\section{Ключевые слова:}

либретто, костюмы и декорации балета «Свадьба Пелея и Фетиды», опера Карло Капроли, мифологические сюжеты в балете и опере. an impression from the overall conception of the production a few centuries after it happened.

Keywords:

libretto, costumes and decorations for the ballet "Les Noces de Pelée et de Thetis," Carlo Caproli's opera, mythological plots in ballet and opera.

Для цитирования/For citation:

Груцынова А.П. Балет «Свадьба Пелея и Фетиды» (1653), сохранившийся в изображениях // ИКОНИ / ICONI. 2021. № 1. С. 75-89. DOI: 10.33779/2658-4824.2021.1.075-089.

$\prod$ очти 370 лет назад в парижском дворце Пти-Бурбон, ныне более всего известном как театральный зал, в котором Ж.-Б. Мольер с труппой ставил собственные пьесы ${ }^{1}$, был показан спектакль. Жанр его на современный взгляд определялся весьма сложно и напоминал скорее длинное описание («итальянская комедия на музыке, смешанная с балетом на тот же сюжет»), в качестве авторов и исполнителей были представители двух культур (итальянской и французской), а либретто спектакля основывалось на мифологическом сюжете. Называлась постановка «Свадьба Пелея и Фетиды».

История этого произведения началась в конце 1653 года, когда кардинал Дж. Мазарини встретился с итальянским аббатом Ф. Бути. К тому времени Бути уже был автором либретто «Орфея» Дж. Росси оперы, поставленной в 1647 году. Теперь по заказу всесильного кардинала Бути написал либретто итальянской комедии на музыке. Текст же балета, «смешанного» с комедией, принадлежал И. де Бенсераду, являвшемуся автором большинства французских придворных балетов того времени (из-под его пера вышли 23 таких произведения).

В начале 1654 года во Францию прибыла итальянская труппа, состоявшая из певцов и музыкантов. Вместе с ними приехал и будущий автор сочинения, которое будет создано на уже написанное либретто - итальянский композитор и скрипач К. Капроли. Однако на французской сцене ставить оперу без танцевальных выходов было немыслимо ${ }^{2}$. Поэтому необходимо было создать на тот же сюжет и балет, что и сделал, по некоторым сведениям, двадцатидвухлетний Ж.-Б. Люлли. Работа над итальянской комедией шла довольно споро, и 14 апреля 1654 года спектакль был поставлен в уже упомянутом знаменитом зале Пти-Бурбон в присутствии королевы Анны Австрийской, английского короля в изгнании Чарльза II и всего французского двора.

Для сюжета был избран древнегреческий миф о смертном Пелее и нереиде Фетиде. Эта история была популярна и в античные времена, но авторов того времени, как правило, интересовал один эпизод этого мифа: борьба Пелея и Фетиды, которая, чтобы избежать брака со смертным, превращалась то в змею, то во льва, то в огонь, то в воду. Для авторов же эпохи барокко именно этот фрагмент интересным быть перестал. В XVII веке свадьба Фетиды и Пелея более всего привлекала возможностью изобразить сначала куртуазные взаимоотношения персонажей, а затем и праздник на Олимпе 
с участием множества божеств. Кроме того, этот пир в мифе одновременно служил и началом новой, тоже чрезвычайно популярной в музыкальном театре, истории - о суде Париса, так как именно на свадьбе Пелея и Фетиды богиня раздора Эрида «потеряла» своё знаменитое яблоко с надписью «прекраснейшей».

Спектакль, поставленный в 1654 году, разумеется, не мог служить полной «иллюстрацией» мифа. В любые времена та или иная мифологическая история при переносе на музыкальную сцену подвергается изменениям. И прежде всего это касается XVII века, когда античный миф — лишь повод “сыграть» очередную куртуазную историю не без её проекции на самый блестящий европейский двор того времени.

Либретто «комедии на музыке» писал итальянец, поэтому в ней (и во включённом в действие балете) имена античных божеств в подавляющем большинстве взяты не из греческой, а из римской традиции (Юпитер, Юнона, Меркурий, Геркулес, Аполлон, статуя Марса). Однако в том же сюжете фигурировал «греческий» кентавр Хирон, окружённый академистами (такое звание имеют в либретто участники так называемой «академии Хирона»), и Прометей, образ которого станет особенно важен в искусстве более позднего времени. Кроме того, были внесены и менее явные, но от этого не менее значительные изменения. Несчастный Прометей, прикованный мстительным Юпитером к скале на вершине Кавказа, терпит ежедневные мучения, доставляемые ему орлом, «который терзает его сердие [курсив мой. - А. Г.]» [5, р. 22] (без сомнений, такая подробность более подходила для придворного балета). Титан по приказанию Юпитера избавлялся от своего наказания за помощь Пелею, а Геркулес выступал лишь в качестве «попутчика", который приводил его на заключавший балет праздник.

В сравнении с мифом был изменён и финал балета, в апофеозе которого от- сутствовала богиня раздора. Сделано это было намеренно и, в отличие от других преобразований, отдельно оговаривалось в предисловии к изданному либретто. Вот как там объяснялось отсутствие Эриды: «было бы позором, если б он [раздор. - А. Г.] появился и <..> возмутил этот восхитительный праздник после того, как сам был из Франции изгнан» [5, p. 4]. Замечание появилось не случайно: в 1654 году страна только начала оправляться от завершившейся за год до того Фронды ${ }^{3}$.

«Свадьба Пелея и Фетиды» в полном смысле слова была произведением "смешанным», так как после каждой сцены итальянской «комедии на музыке» (то есть, оперы) следовало балетное entrée (всего их было десять), связанное с событиями исполненной оперной сцены. По традиции французского балета каждое entrée содержало, кроме собственно танцев, монологи отдельных персонажей, нередко довольно продолжительные. Забавно, но при том, что музыка оперы Капроли не сохранилась, от спектакля остались именно балетные выходы ${ }^{4}$. В этом видится некий знак: в самом деле, Париж всегда был более склонен к балету, чем к опере, сохранив эту любовь даже при кардинале Мазарини, который откровенно покровительствовал итальянскому жанру. Вышло очень по-французски: опера утеряна, а балетные выходы - сохранились. Как весьма точно замечал $\Phi$. Боссан, «при наличии одинаковой отправной точки в Париже химическая смесь поэзии, музыки и танца породила придворный балет, в то время как во Флоренции смесь тех же ингредиентов породила оперу» [1, с. 152].

В балетных entrée действуют как персонажи персонифицированные (Аполлон и Музы, Юнона 5 , Гименей, Геркулес), так и обобщённые, которые, чтобы отличить их от оперных хоров, в либретто названы «немыми хорами» (chour muet). Таковы «немые хоры» волшебников, искателей кораллов, фурий ревности, дикарей и 
дикарок, дриад, рыцарей Фессалии, придворных и искусств (свободных и механических).

Танцевальные выходы «Свадьбы Пелея и Фетиды», завершающие сцены оперы, состояли из двух отграниченных друг от друга частей. Первая - собственно entrée, вторая - так называемая air следующий за ним танец. Интересно, что каждое последующее entrée становится все более причудливым в выборе персонажей, в нём участвующих.

Пролог комедии показывал долину родной Пелею Фессалии, где на горе́ располагаются девять муз и Аполлон (ил. 1), которые затем спускаются вниз, «заполняют театр и составляют первое entrée балета» [5, p. 5].

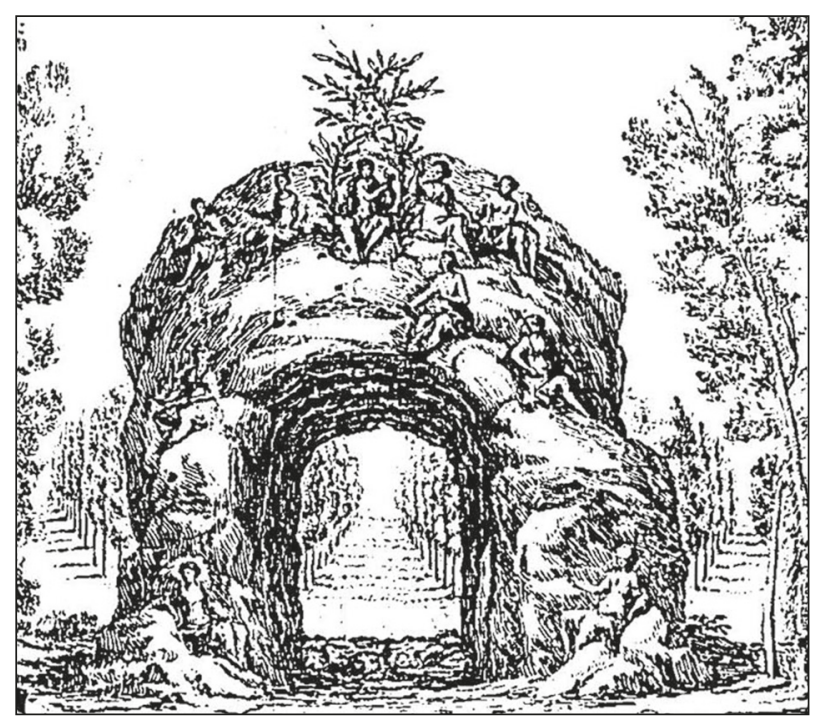

\section{Ил. 1. Пролог - Аполлон и музы (Фрагмент изображения)}

Первая сцена первого акта проходила в пещере кентавра Хирона (ил. 2), который советует Пелею, чтобы тот «на Кавказе просил содействия Прометея, тайно укравшего на небе огонь и унёсшего все великие и возвышенные знания" [5, p. 13]. В конце сцены, когда Пелей соглашается последовать совету Хирона, волшебники, присутствующие при всём этом, «очаровывают танцем» [5, р. 13].

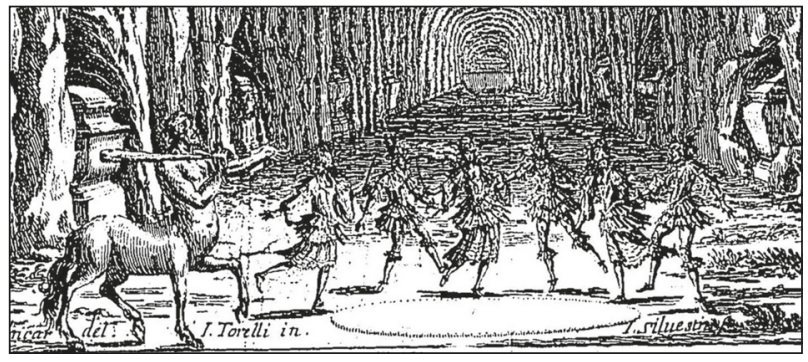

\section{Ил. 2. 1 д., 1 си. - Хирон, Пелей и волшебники (фрагмент изображения)}

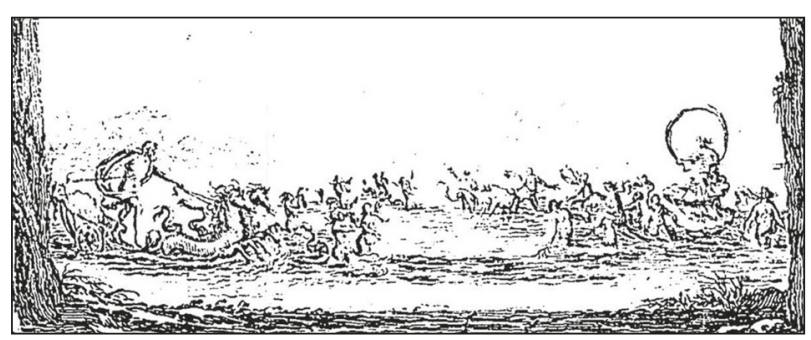

\section{Ил. 3. 1 д., 2 си. - Нептун (слева) и Фетида (справа) (фрагмент изображения)}

Вторая сцена первого акта представляла зрителям вид на море (ил. 3), где «Фетида показывается на огромной раковине, сопровождаемая морским полубогом и окружённая прекрасной группой искателей кораллов» [5, р. 16]. Сцена отказа Фетиды от брака с Нептуном и последующей грозы, вызванной рассерженным богом морей, завершалась выходом искателей кораллов, которые, «чтобы переждать бурю, устраивают ради развлечения танец" [5, p. 16].

В третьей сцене брак Фетиде предлагал спустившийся на огромном облаке с небес Юпитер (рис. 4) - и тоже получал отказ. Но следом являлась ревнивица Юнона, которая «прибывает в вихре не менее бурном, чем её гнев» [5, p. 20] и призывала на помощь фурий ревности (ил. 5). Четвёртое entrée посвящалось именно этим персонажам.

Первая сцена второго акта происходила на вершине Кавказа, где терпел мучения Прометей (ил. 6), к которому 


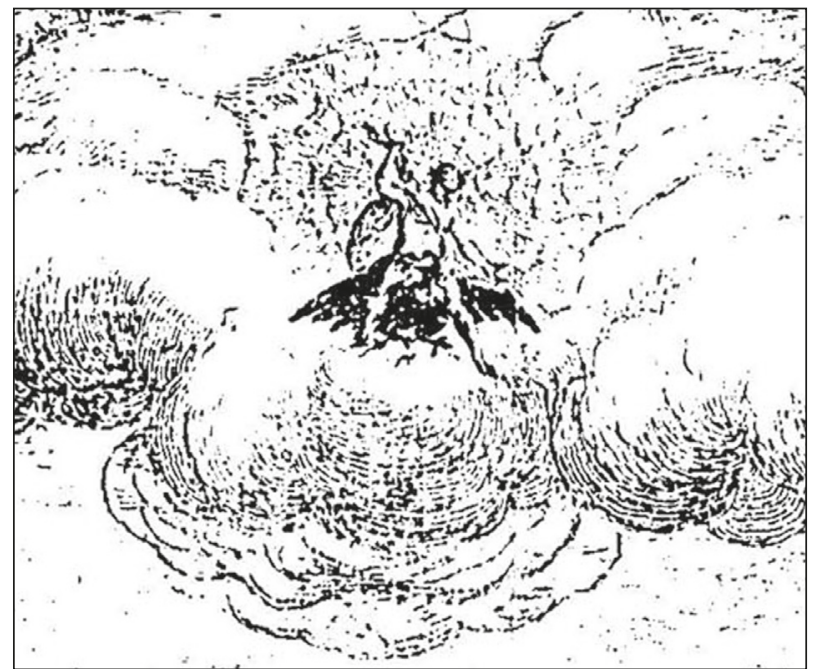

Ил. 4.1 д., 3 си. - Юпитер (Фрагмент изображения)

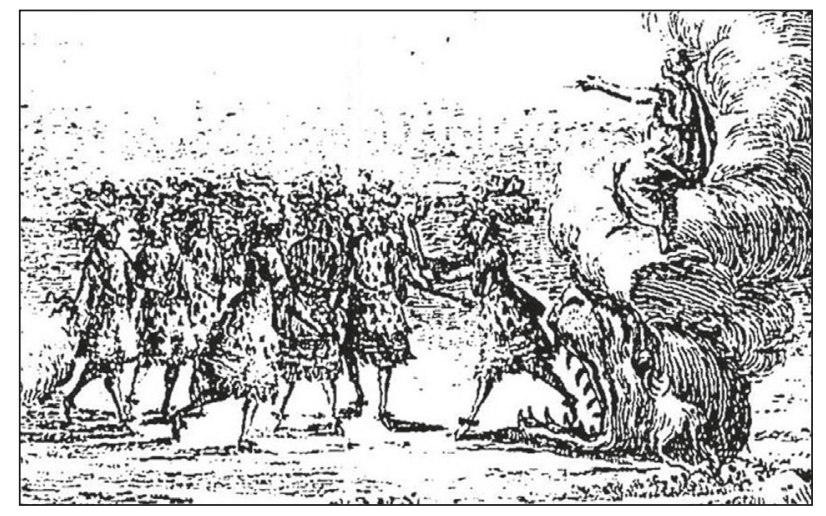

Ил. 5.1 д., 3 си. - Юнона и фурии (Фрагмент изображения)

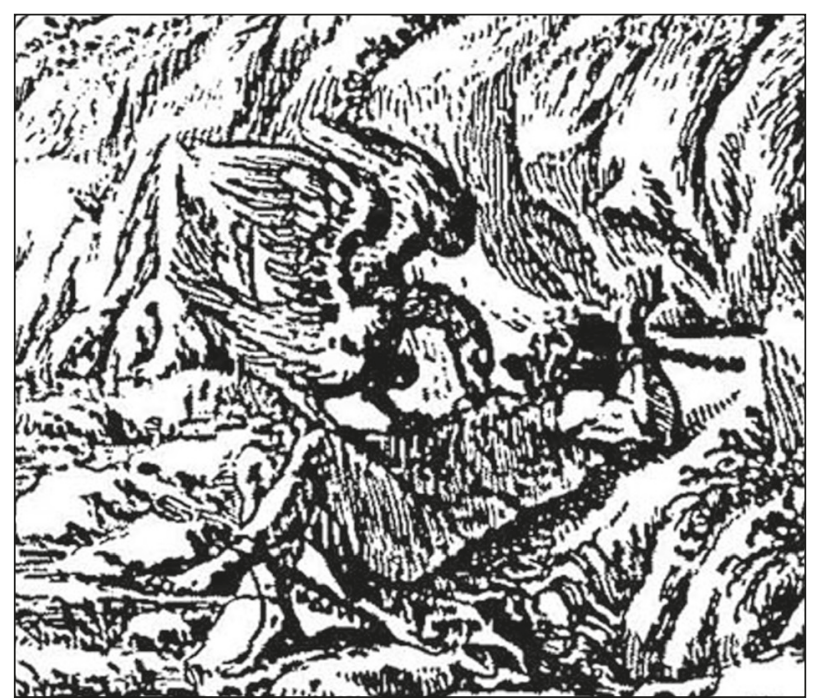

Ил. 6. 2 д., 1 си. -мучимый Прометей (фрагмент изображения) является за советом Пелей (ил. 7). Титан «уверяет, что Дельфийский оракул предсказал Фетиде сына более великого, чем его отец: <...> потому Юпитер, без сомнения, принуждён будет отказаться от своих претензий» [5, р. 22]. Завершалась сцена выходом дикарей и дикарок (ил. 8), выражавших в танце своё ликование по поводу освобождения Прометея, которое последует за его советом Пелею.

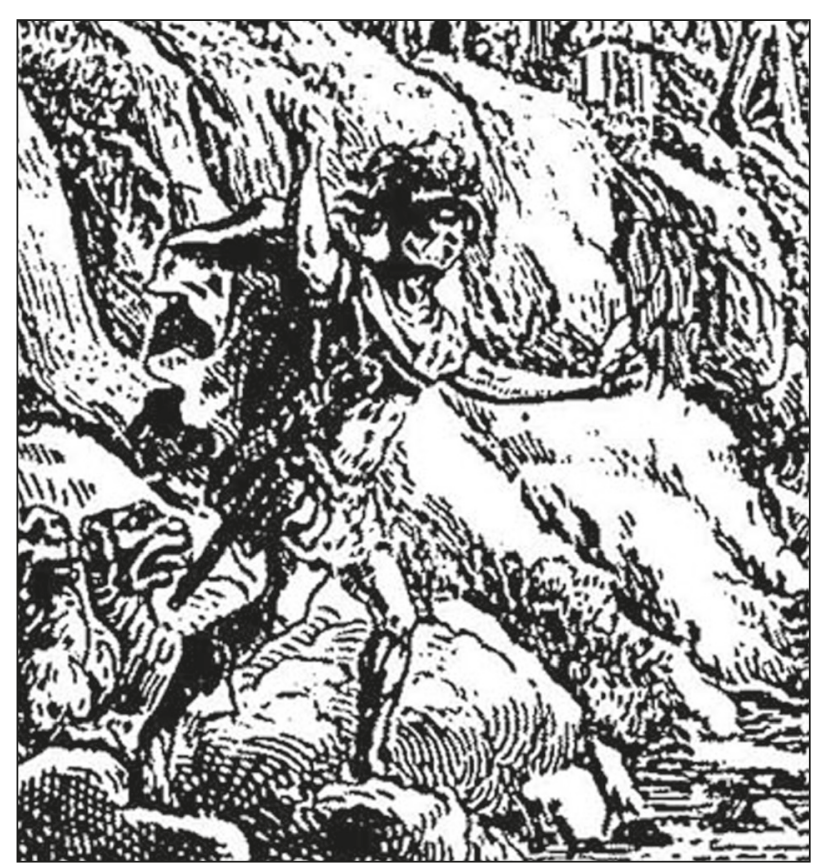

Ил. 7. 2 д., 1 си. - Пелей

(Фрагмент изображения)

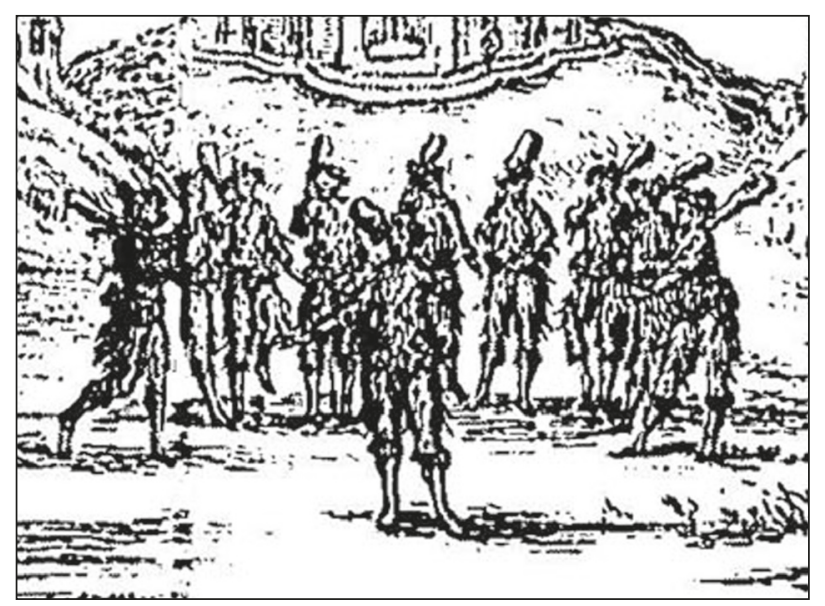

Ил. 8. 2 д., 1 си. - дикари (фрагмент изображения) 


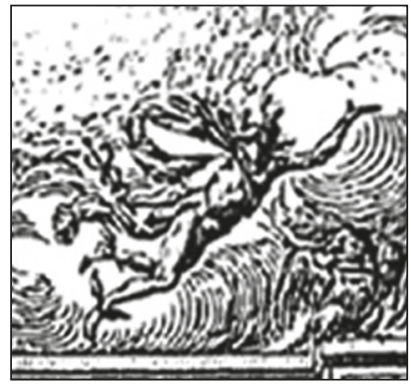

Ил. 9.2 д., 2 си. улетающий Меркурий (фрагмент изображения)

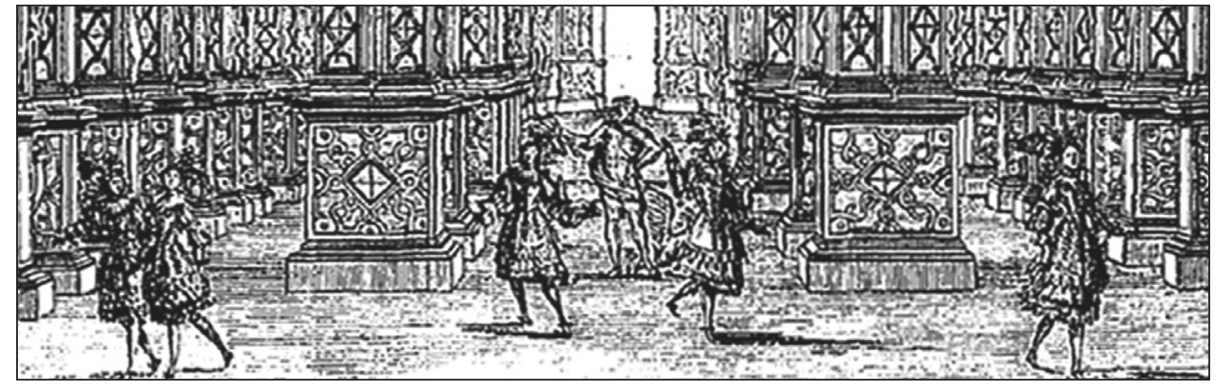

Ил. 10. 2 д., 2 си. - Юпитер и дриады (фрагмент изображения)
Вторая сцена показывала дворец Юпитера, тайно выстроенный из золота и драгоценных камней специально для того, чтобы сочетаться браком с Фетидой. Однако узнав от Меркурия (ил. 9) о сделанном Оракулом предсказании, Юпитер отказывался от своего намерения и возвращался на небо. В это время дриады, которые присутствовали при разговоре, «прислушиваясь, чтобы дать отчёт Юноне обо всех мыслях Юпитера, изъявляют в танце свою радость» [5, p. 24] (ил. 10).

Пожалуй, самая рыцарственная сцена «Свадьбы Пелея и Фетиды» - третья сцена второго акта. В ней рыцари Фессалии, «удручённые жестокостью Фетиды по отношению к их царю Пелею, затевают между собой битву в честь Марса» [5, p. 27] (ил. 11). Они надеются, что, приняв такого рода жертвоприношение, воинственный бог, в свою очередь, попросит Венеру помочь Пелею в любовной истории. Особенно характерным для XVII века выглядит краткое завершение изложения этой сцены: «статуя Марса начинает говорить и предсказывает всяческое благополучие; <...> рыщари снимают вооружение и таниуют [курсив мой. - А. Г.]» [5, р. 28].

Третий акт - счастливая развязка столь долгой истории. В первой сцене Хирон в окружении собственных академистов советовал Пелею явиться к Фетиде «с последней горячностью любви» [5, р. 29]. Академисты же «в танце изъявляют радость по поводу возвращения Пелея» [5, р. 29] (ил. 12).

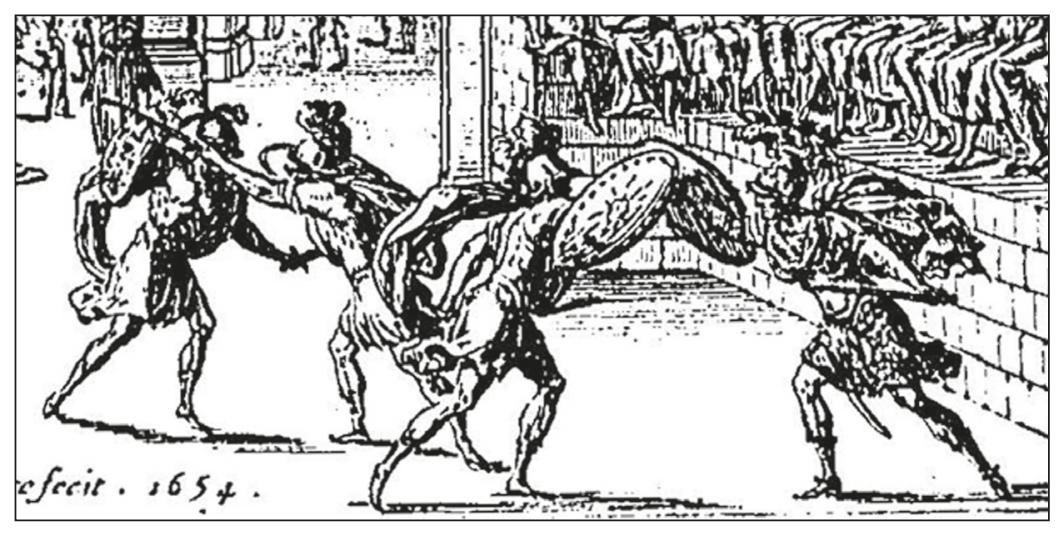

Ил. 11. 2 д., 3 си. - битва рыщарей Фессалии (фрагмент изображения) 
Во второй сцене третьего акта Пелей всё-таки добивается согласия Фетиды на брак (ил. 13) и «весь двор Пелея танцует с беспримерным ликованием» [5, p. 31].
Последняя сцена представляла собой огромную картину празднества, на котором присутствовали практически все олимпийские божества (ил. 14), амуры

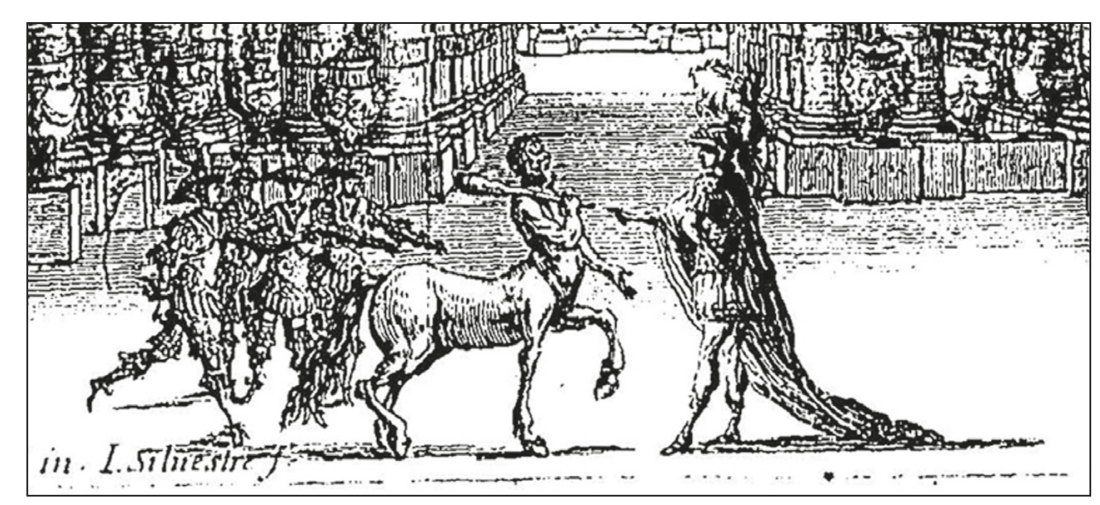

Ил. 12.3 д., 1 си. - академисты, Хирон и Пелей (фрагмент изображения)

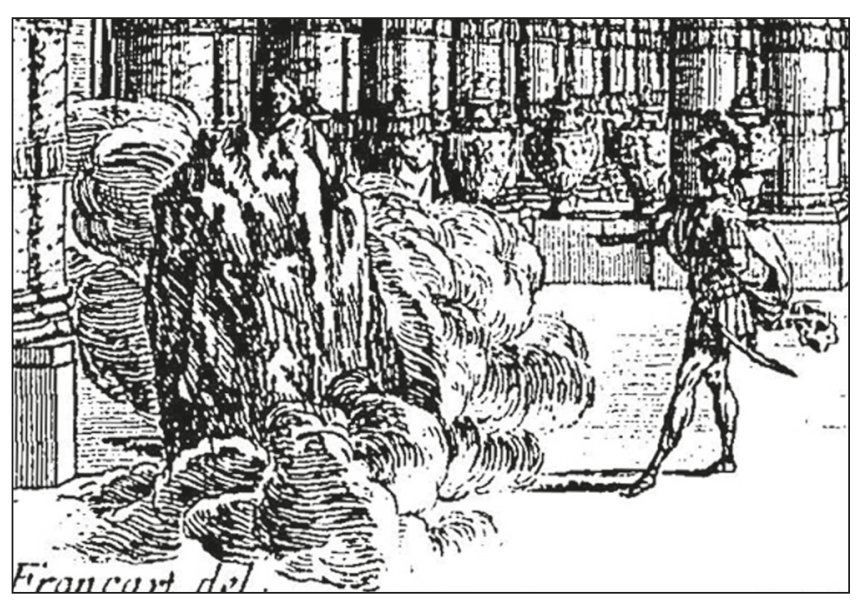

Ил. 13. 3 д., 2 си. - Фетида (слева) и Пелей (справа) (фрагмент изображения)

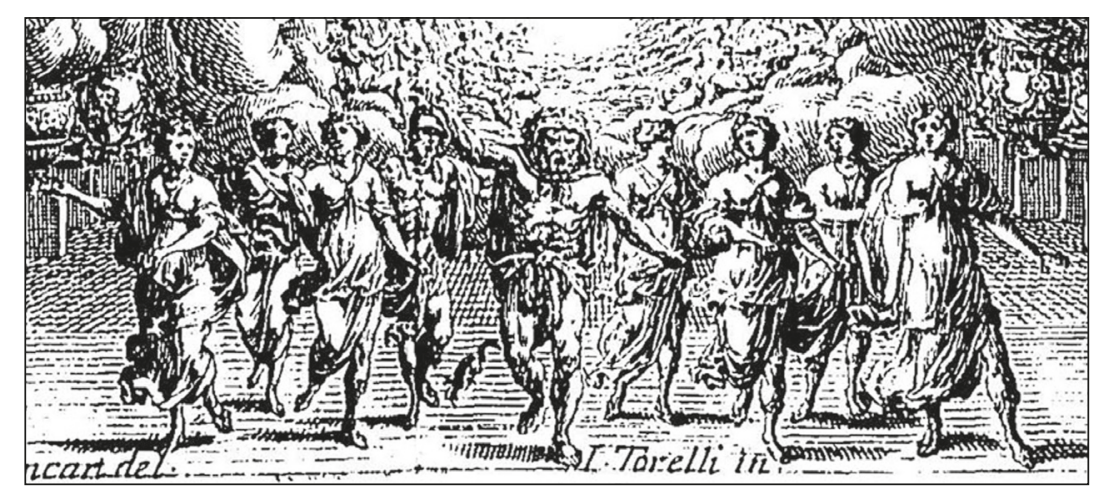

Ил. 14. 3 д., 3 си. - празднество олимпийских божеств (фрагмент изображения) 


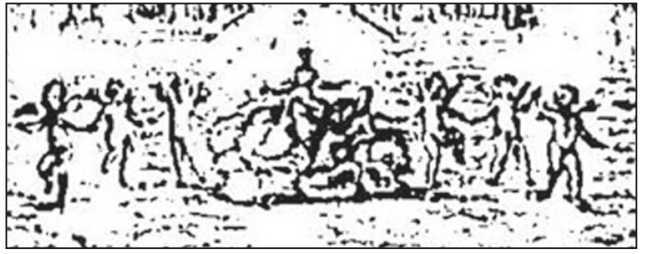

Ил. 15. 3 д., 3 си. - амуры, таниующие на небесах (фрагмент изображения)

и Искусства, изобретённые, как говорится в либретто, Прометеем (свободные Геометрия, Музыка, Диалектика, Грамматика, Риторика, Астрология, Арифметика, и механические - Война, Агрикультура, Навигация, Охота, Ювелирное дело, Живопись, Хирургия). Завершалось всё гран-балетом на земле, «тогда как маленькие Амуры, в свою очередь, танцуют на небесах» [5, p. 35] (ил. 15).

Если в наше время костюмы и сценография - зачастую всего лишь сопутствующая составляющая часть спектакля (от которой иногда можно и удачно отказаться), то в «Свадьбе Пелея и Фетиды», как и в прочих постановках того времени, визуальный ряд по праву стоял рядом с хореографией и, вероятно, представлялся даже чем-то более важным, чем музыкальное сопровождение. Недаром помимо либреттиста и композиторов одним из важнейших авторов представления стал художник, создавший декорации и сценические машины Дж. Торелли. Его «театральные перемены», видимо, были столь впечатляющи, что после премьеры «Свадьбы Пелея и Фетиды» была издана отдельная брошюра (параллельно - на итальянском и французском языках) под названием «Декорации и машины Свадъбы Фетиды, королевского балета; представленного в зале дю Пти-Бурбон, Жака Торелли, изобретателя. Посвящено Его Преосвященству кардиналу Мазарини» [4].

Каждая перемена декораций и связанное с ними действие описано в этой книге любовно и подробно, со скрупулёзно прорисованными гравюрами. Вот как,

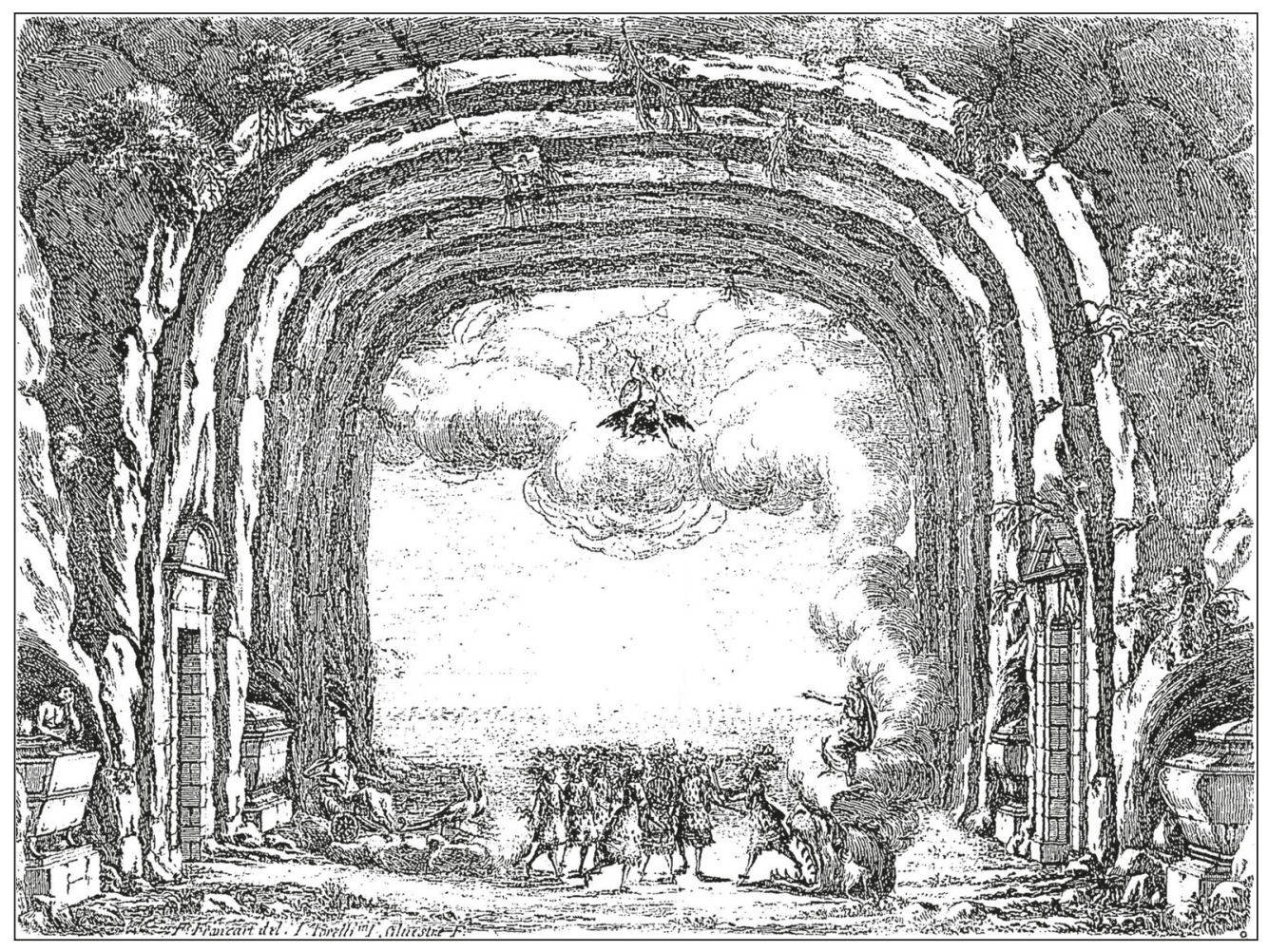

Ил. 16. 1 д., 3 си. - вид сцены 


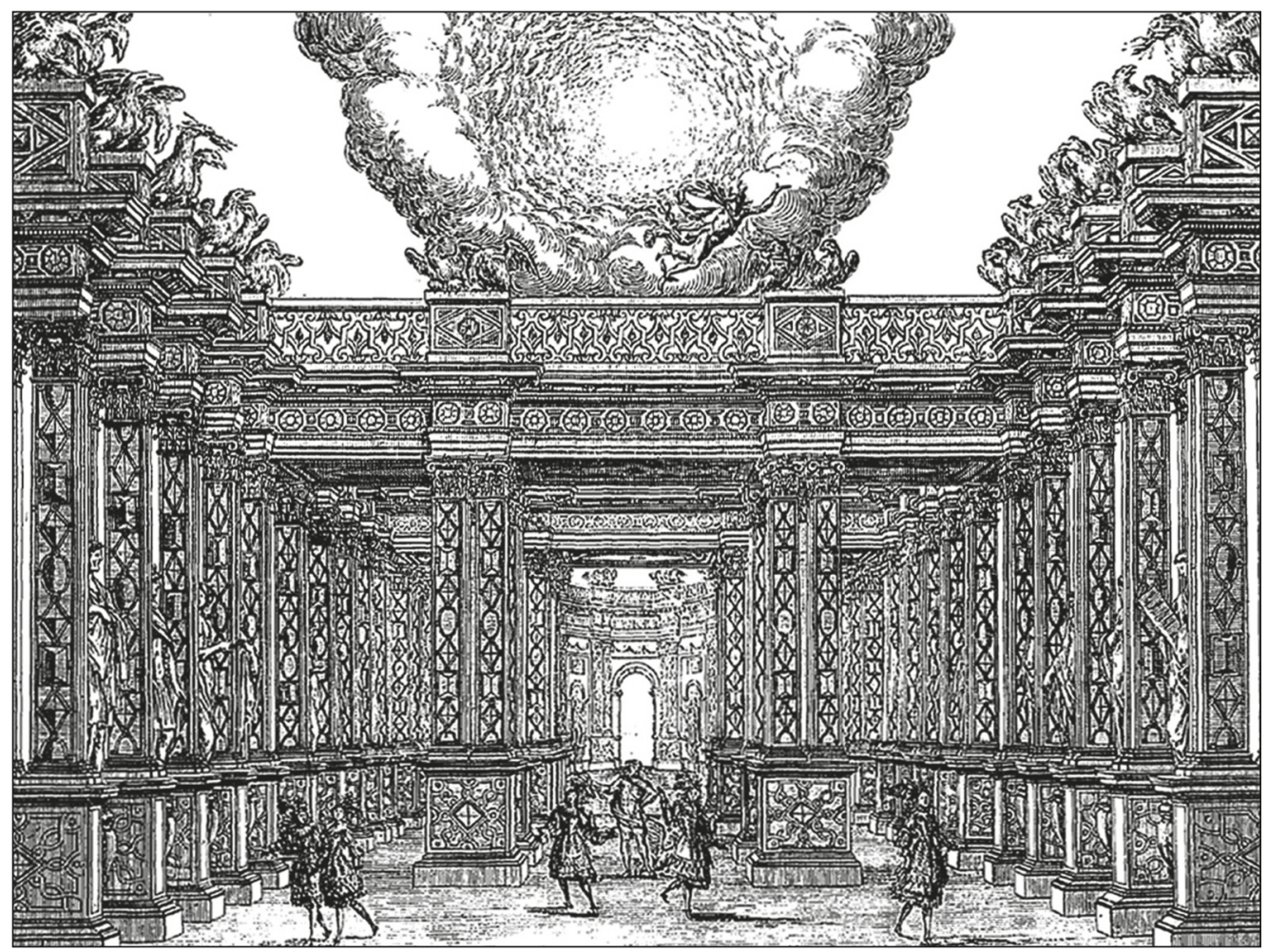

Ил. 17. 2 д., 2 си. - вид сцены

например, описывается сцена появления фурий ревности: «Юнона вызывает из ада монстра, который, ужасный видом, показывается из-под земли, испускает пламя и дым, смешанные с серой, и извергает четырёх фурий, которые вместе со многими другими составляют танец сколь странный, столь и любопытный» [4] (ил. 16).

Ещё более подробного описания удостаивается тайно выстроенный Юпитером дворец, «замечательный архитектурой и коринфскими колоннами из золота; на столбах балюстрады золотые статуи орлов. На лицевой стороне колонн видно множество драгоценных камней различных цветов, оправленных в ляпис-лазурь. Между двойными пилястрами возвышаются статуи многочисленных ушедших древних Божеств» [4] (ил. 17).

Столь же мельчайшими подробностями отличаются и эскизы множества костюмов, созданных для этого спектакля Ж. Жиссе. Так как «Свадьба Пелея и Фети- ды» была произведением «смешанного» жанра, то и исполнители тоже были разнообразны. Роли в собственно «итальянской комедии на музыке» были поручены певцам, приехавшим из Италии вместе с композитором Капроли. Это известный в то время кастрат Дж. Киарини (Пелей) (ил. 18), В. Капроли (Фетида) (ил. 19), А. д’Имола (судя по эскизам костюмов, он исполнял роли двух божеств - Нептуна и Юпитера) (ил. 20-21), англичанин Т. Стаффорд (Прометей) (ил. 22-23) и даже славянин Ф. Гигоф, по одним сведениям - поляк, по другим - русский (кентавр Хирон) (ил. 24).

Для нас же особенно интересны исполнители балетных entrée. Листая либретто, можно найти практически все имена тех, кто «представлял» дриад, нереид, искателей кораллов и пр. В большинстве своём это были великосветские любители, которые, как это зачастую случалось в то время, в мастерстве танца не уступали профессионалам. Россыпь имён читается как роман А. Дюма: герцогиня 


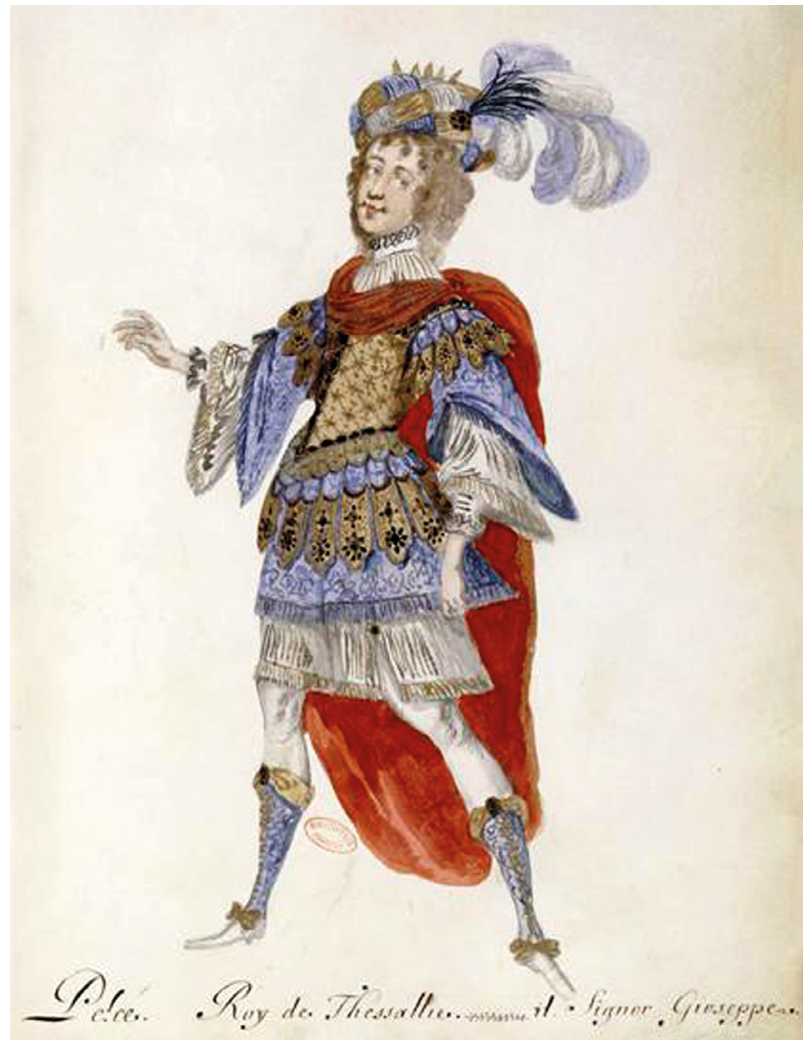

Ил. 18. Эскиз костюма Пелея

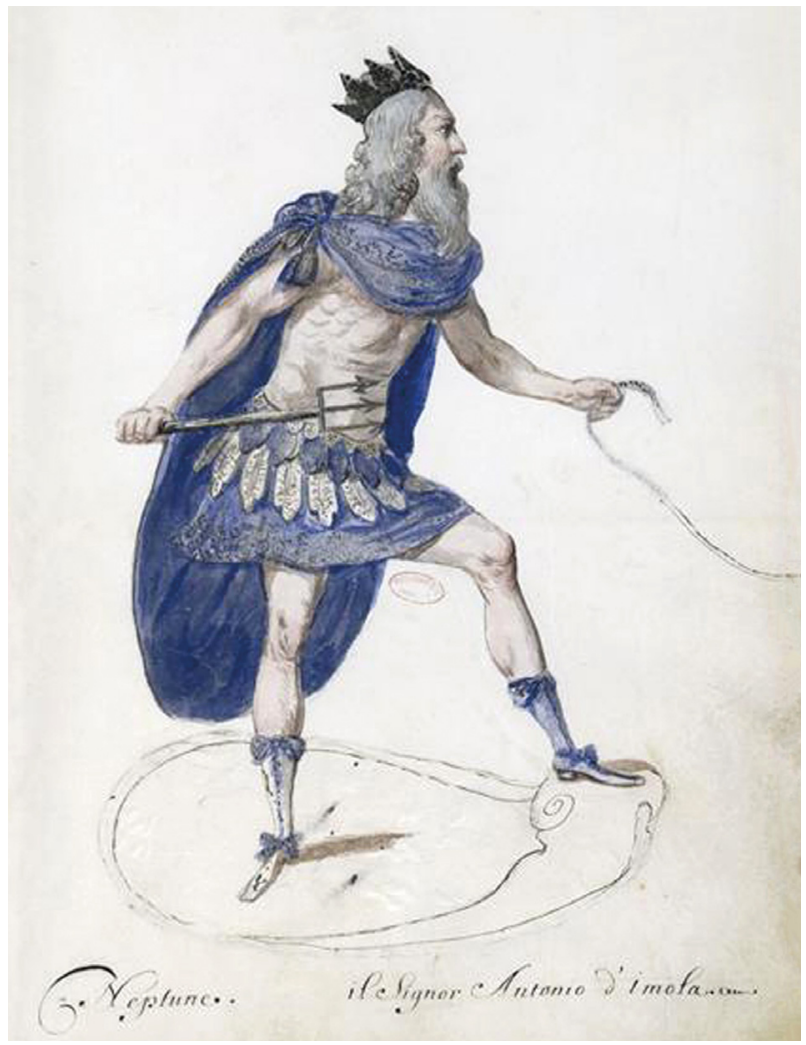

Ил. 20. Эскиз костюма Нептуна

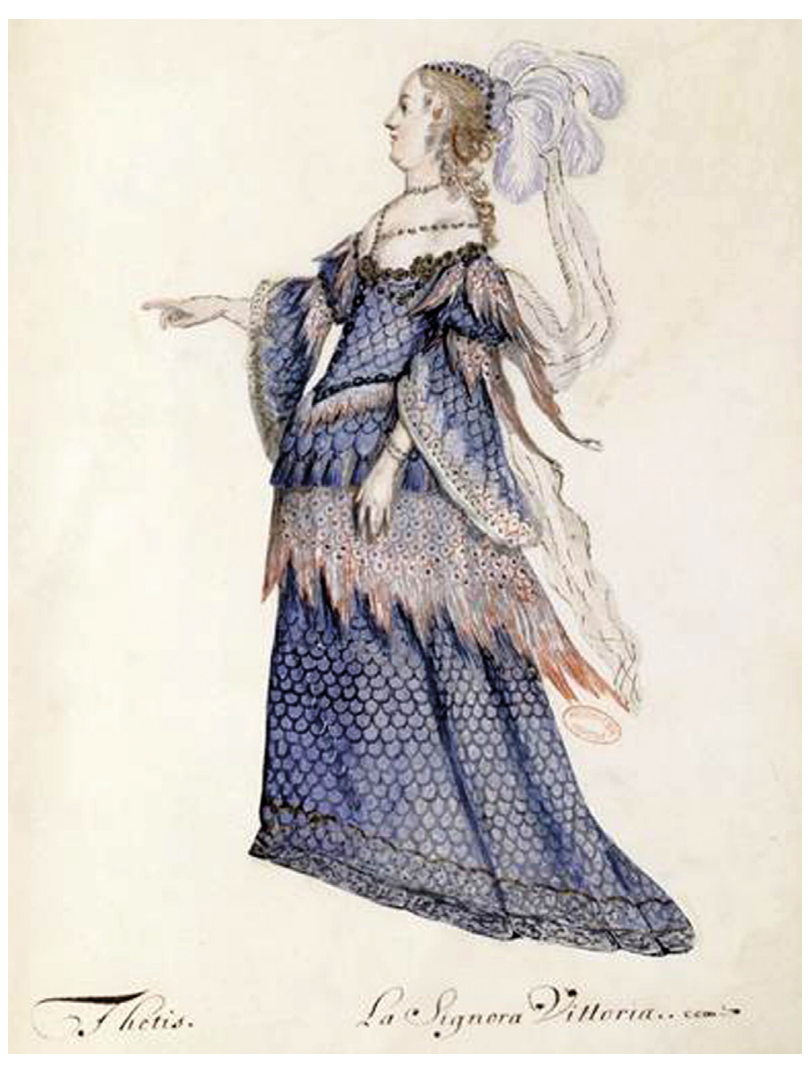

Ил. 19. Эскиз костюма Фетиды

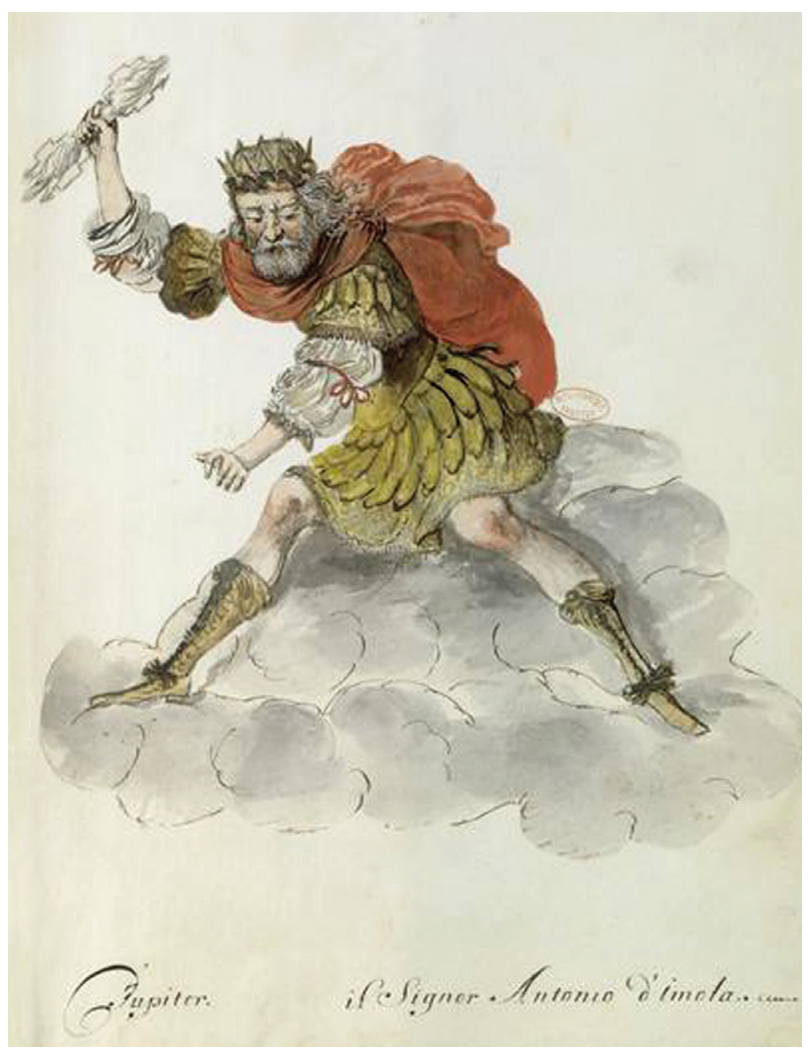

Ил. 21. Эскиз костюма Юпитера 


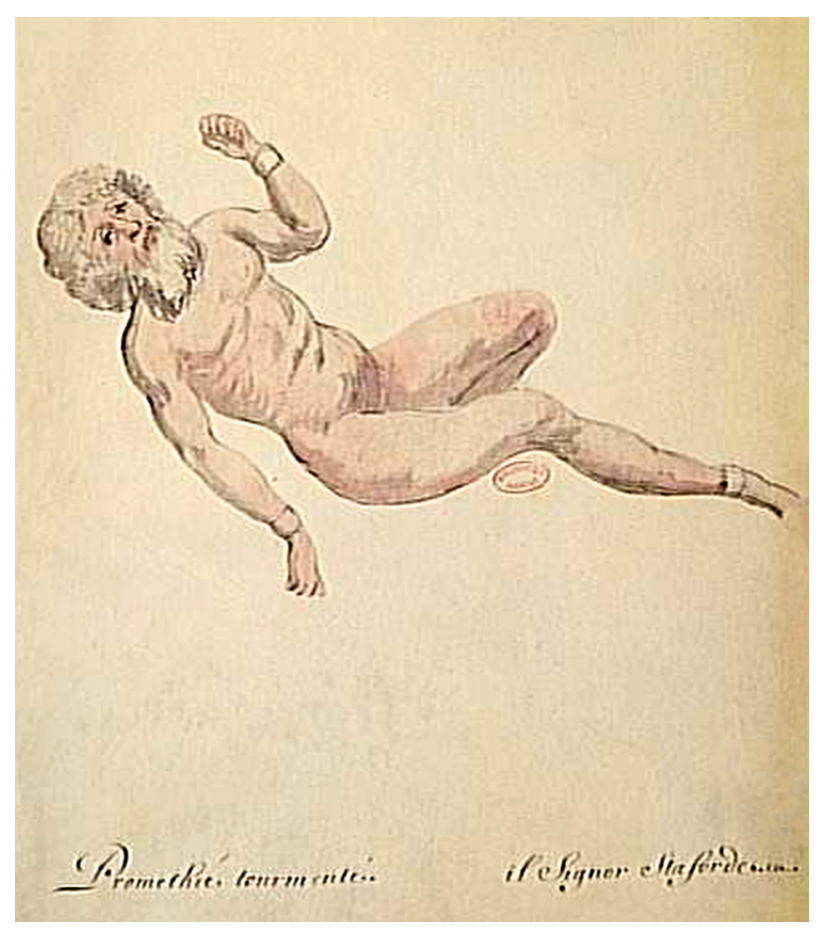

Ил. 22. Эскиз костюма мучимого Прометея

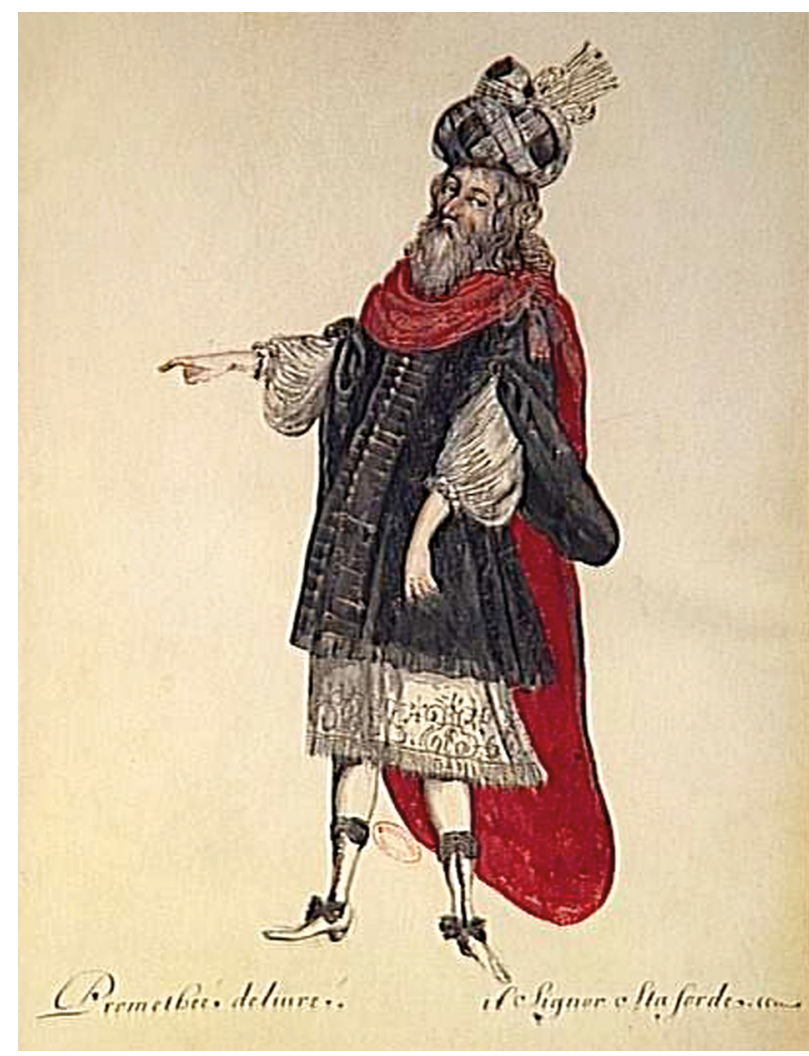

Ил. 23. Эскиз костюма освобождённого Прометея де Креки, герцог де Жуайёз, принцесса де Конти, граф де Сент-Эньян и граф де Сент-Эньян-младший, мадемуазель д’Эстре... Некоторые из них выходили в нескольких entrée.

Последовательно в шести ролях появлялся перед зрителями 16-летний Людовик XIV, первым образом которого в этом балете стал Аполлон (ил. 25) (роль, уже «опробованная» им за год до этого в «Королевском балете Ночи»), а далее последовательно - фурия, дриада, академист (ил. 26), придворный и Война (ил. 27). Его младший брат, четырнадцатилетний принц Филипп, официально носивший титул «Месье, единственный брат короля», выходил в двух ролях — искателя кораллов и Амура (ил. 28) (эскизы некоторых костюмов могут служить своего рода миниатюрными портретами настолько индивидуальны в них черты лица $\left.{ }^{7}\right)$ Помимо всех прочих, в роли одной

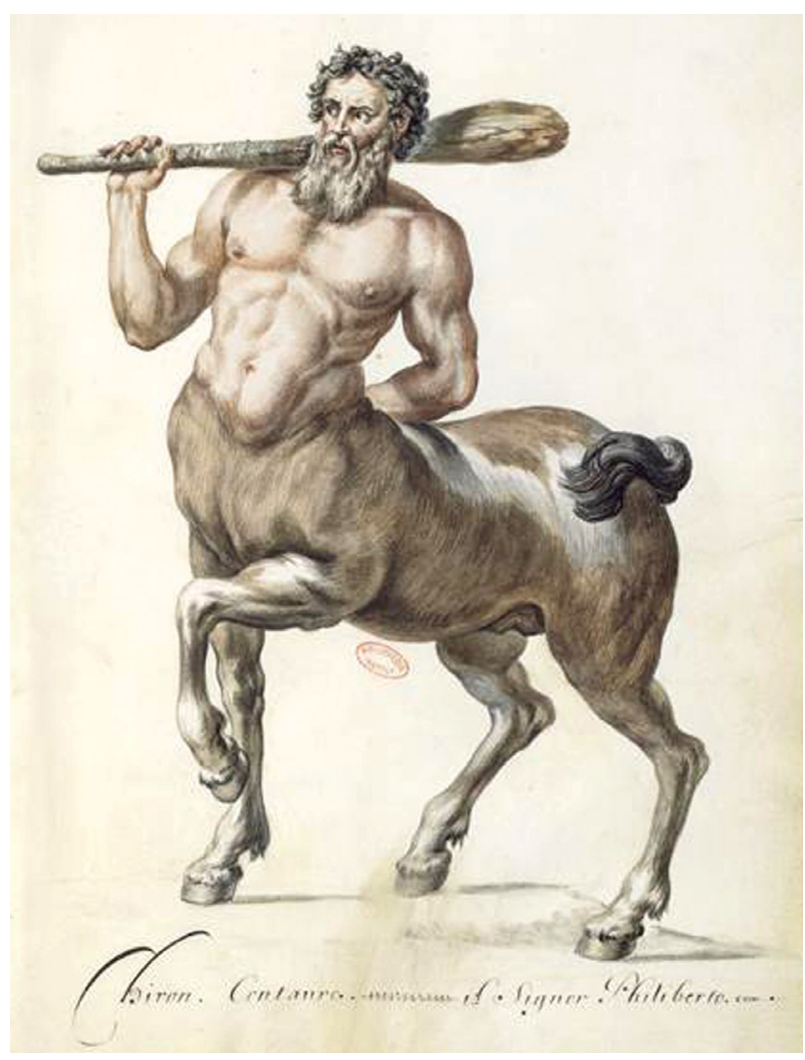

Ил. 24. Эскиз костюма Хирона 


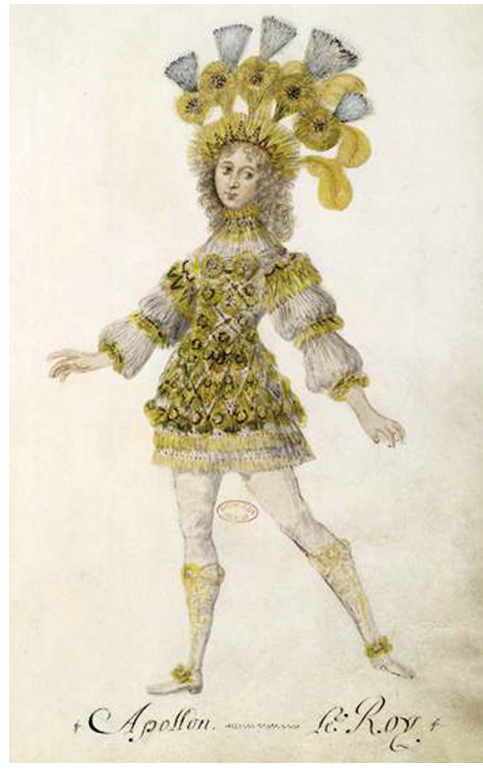

Ил. 25. Эскиз костюма Аполлона

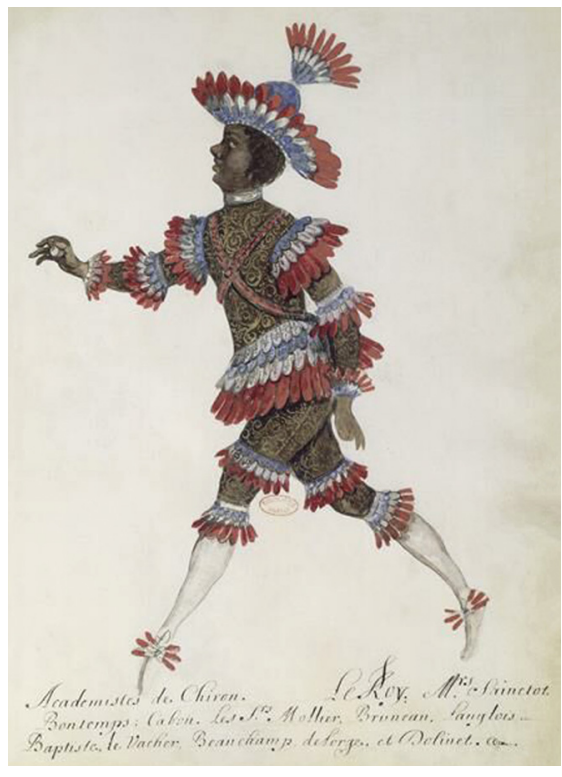

Ил. 26. Эскиз костюма академист

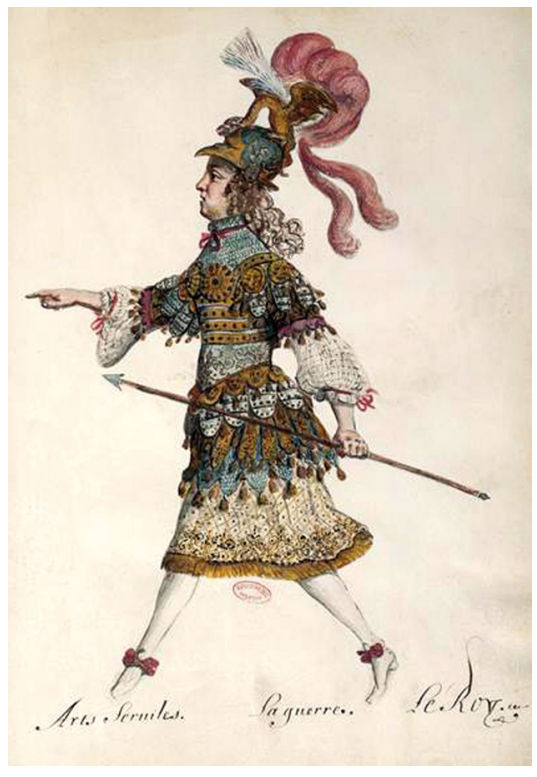

Ил. 27. Эскиз костюма Войны

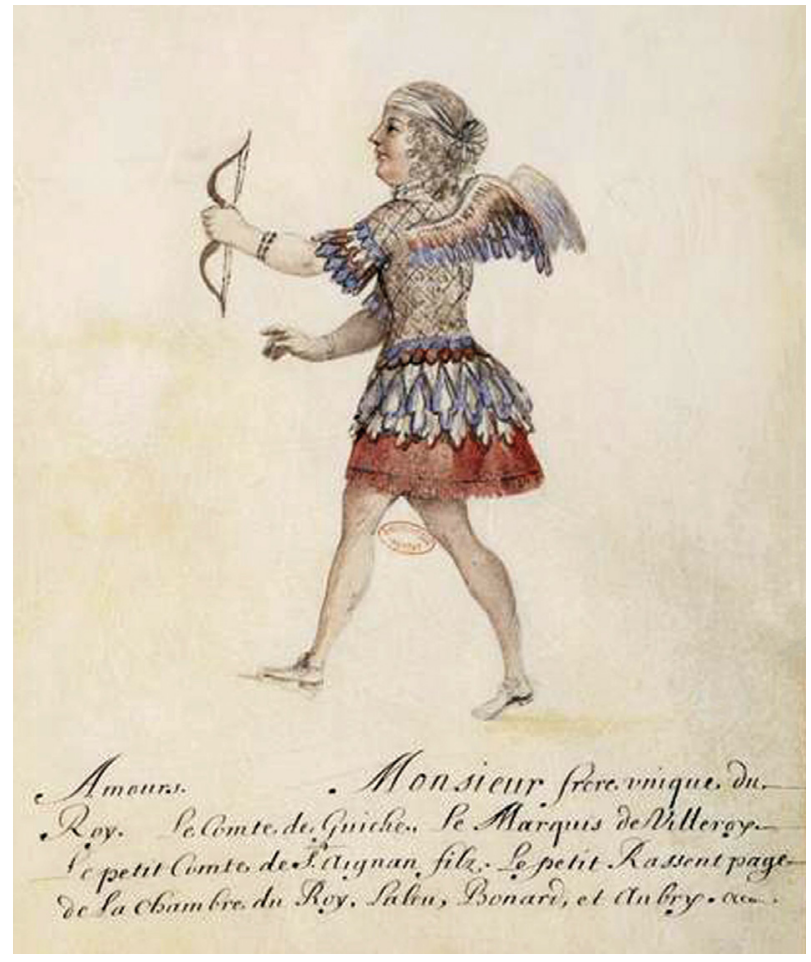

Ил. 28. Эскиз костюма Амура

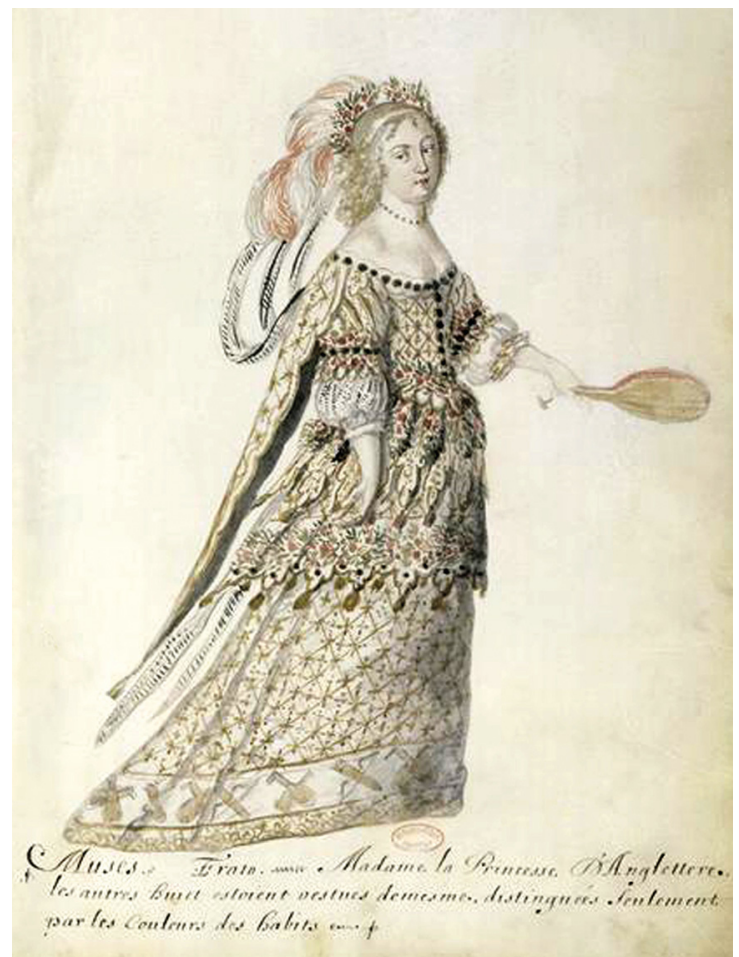

Ил. 29. Эскиз костюма музы Эрато 
из муз (Эрато) выступила десятилетняя английская принцесса Анна-Генриетта - дочь казнённого в Англии короля Карла І и будущая невеста Месье (ил. 29).

Продолжая рассказ о дамах, принимавших участие в «Свадьбе Пелея и Фетиды», можно указать на одну характерную для придворного спектакля того времени деталь: фурии ревности или увлечённо следящие за Юпитером дриады были ролями для мужчин. Тогда как девять Муз и Свободные Искусства представлялись дамами. Вот уж действительно, «в галантной культуре дама всегда молода, прекрасна лицом и душою, и иной быть не может. Изображать безобразных старух, вроде феи Карабос, дело мужчин» [2, с. 43].

Кроме дилетантов-придворных в балете принимали участие и профессионалы. Три роли (волшебника, фурии и академиста) исполнял «сеньор Батист» - предположительный автор музыки балетных выходов Ж.-Б. Люлли. Под тремя масками (фурии, дриады и академиста) скрывался «сеньор Мольер». Уже знаменитый в то время восемнадцатилетний П. Бошан (танцовщик, а впоследствии знаменитый хореограф), соседствующий с Мольером, к трём уже упомянутым ролям добавил и ещё одну - одного из Механических Искусств (любопытно, что в либретто указана Живопись, тогда как эскиз, подписанный «господин Бошан», относится к другому искусству - Хирургии (ил. 30).

Участие короля в балете обычно расценивается исследователями как дополнительное подтверждение «центрального» в то время положения абсолютного монарха, которое проецировалось из сферы государственного устройства на театральный жанр. Подчёркивается это и избранием «любимого» образа Людовика XIV - Аполлона, Феба или Восходящего солнца ${ }^{8}$. Несомненно, это так. Однако следует принять во внимание несколько дополнительных деталей. Читая либретто балета, легко заметить, что король исполнял в «Свадьбе Пелея и Фетиды»

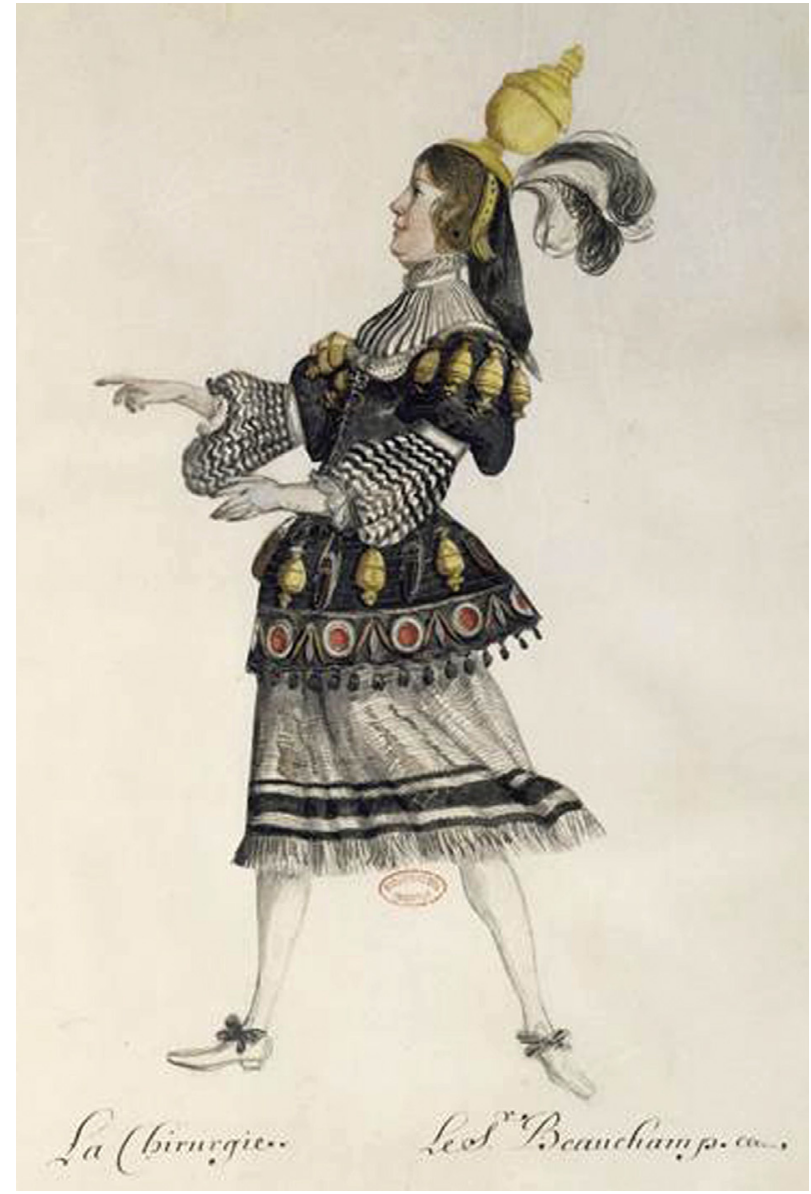

Ил. 30. Эскиз костюма Хирургии

больше ролей в балетных выходах, чем любой другой её участник (включая таких профессионалов, как Бошан, Мольер и Люлли). Впрочем, нередко это были роли не центральные (помимо, пожалуй, уже упомянутого Аполлона), а входящие в ансамбль. Юный Людовик оказывался лишь одним из нескольких (фурий, дриад, академистов и т. п.), и в этом тоже видится своеобразная игра в «добрые старые времена", когда король был лишь первым среди равных. Однако ему предназначалось большее, чем у других, количество стихотворных строк в тех entrée, где он появлялся (ему же принадлежит и абсолютный "рекорд» - 24 строки). С ним не мог соперничать даже его брат Филипп. И это обратная сторона такого рода «проецирования» центрального положения венценосного исполнителя, когда ни один из прочих участников 
не мог дольше короля привлекать внимание публики.

Показанная в Пти-Бурбон 14 апреля 1654 года «Свадьба Пелея и Фетиды» была за два месяца показана девять раз. Кастиль-Блаз добавляет, что «те же актёры давали представление перед публикой в театре Марэ на улице Вьель-дю-Тампль» [3, p. 72].
Сюжет о свадьбе Пелея и Фетиды, испытанный в XVII и XVIII веках в разных произведениях разных искусств, вернётся и в XIX веке. В 1816 году им воспользуется Дж. Россини для создания кантаты, а в 1876 - М. Петипа в балете «Приключения Пелея», возвращающем на сцену музыкального театра «пересказ» почти полной версии мифа.

\section{a ПРИМЕчАНИЯ}

1 Кроме того, там проходили придворные праздники (например, в их числе был и первый балет — «Комедийный балет королевы», 1581).

2 Как известно, даже в XIX веке к постановке на сцене парижской Оперы допускались лишь оперы, содержащие балетные сцены. Благодаря этому требованию в вагнеровском «Тангейзере» появилась знаменитая сцена вакханалии.

3 В том же году был поставлен знаменитый «Королевский балет Ночи», который негласно считается празднеством по случаю завершения смуты.

4 Здесь мы не говорим о либретто и изображениях.

5 Юнона - единственное действующее лицо, фигурирующее как среди «поющих", так и среди «танцующих». Причём, «поющей»
Юноной был итальянец Дж. Пиньяни, а «танцующей» - француженка мадам де Комманж.

6 Фрагменты этих гравюр мы уже приводили выше в качестве иллюстраций к тексту. Интересно, что на каждой из гравюр в одновременном изображении «собраны» не только все подробности декорационного решения, но и все основные «события» конкретной сцены. Например - появление перед Фетидой Юпитера, последующий выход Юноны и, наконец, танец фурий ревности (ил. 16). 7 Можно, например, сравнить эскиз костюма музы Эрато и портрет принцессы Анны-Генриетты.

8 Широко известно, что именно поэтому Людовик XIV получил своё определение в истории как «король-солнце».

\section{的 лиТЕРАТУРА}

1. Боссан Ф. Людовик XIV, король-артист. М.: Аграф, 2002. 266 с.

2. Булычёва А. Сады Армиды. М.: Аграф, 2004. 488 с.

3. Castil-Blaze. Opera Italien (1548-1856). Paris: Castil-Blaze, 1856. 544 p.

4. Décorations et machines aprestées aux Noces de Tétis, ballet royal; représentées en la salle du Petit-Bourbon, par Jacques Torelli, inventeur. Dediées a l'Eminentissime Prince Cardinal Mazarin. [Paris, 1654]. [n. p.].

5. Les Nopces de Pelée et de Thetis. Comedie Italienne en Musique, entremêlée d'un ballet sur le même sujet, dansé par se Majesté. Paris: Chez Robert Ballard, seul Imprimeur du Roy pour la Musique, 1654. 43 p.

\section{Об авторе:}

Груцынова Анна Петровна, доктор искусствоведения, доцент, профессор кафедры междисциплинарных специализаций музыковедов, Московская государственная консерватория имени П.И. Чайковского; профессор кафедры хореографии, РАТИ - ГИТИС (125009, г. Москва, Россия), ORCID: 0000-0003-4014-4722, anna_gru@mail.ru 


\section{Q REFERENCES}

1. Bossan F. Lyudovik XIV, korol'-artist [Louis XIV, King Artist]. Moscow: Agraf, 2002. 266 p.

2. Bulycheva A. Sady Armidy [The Gardens of Armida]. Moscow: Agraf, 2004. 488 p.

3. Castil-Blaze. Opera Italien (1548-1856). Paris: Castil-Blaze, 1856. 544 p.

4. Décorations et machines aprestées aux Noces de Tétis, ballet royal; représentées en la salle du Petit-Bourbon, par Jacques Torelli, inventeur. Dediées a l'Eminentissime Prince Cardinal Mazarin. [Paris, 1654]. [n. p.].

5. Les Nopces de Pelée et de Thetis. Comedie Italienne en Musique, entremêlée d'un ballet sur le même sujet, dansé par se Majesté. Paris: Chez Robert Ballard, seul Imprimeur du Roy pour la Musique, 1654.43 p.

\section{About the author:}

Anna P. Grutsynova, Doctor of Arts, Associate Professor, Professor of the Division for Interdisciplinary Musicological Studies, Moscow State P.I. Tchaikovsky Conservatory; Professor of the Department of Choreography, Russian Institute of Theatre Arts (125009, Moscow, Russia),

ORCID: 0000-0003-4014-4722, anna_gru@mail.ru

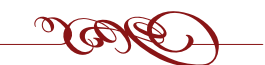

